\title{
Determinant of Capital Structure of Cigarette Firm Listed on IDX
}

\author{
Nindi Vaulia Puspita ${ }^{1^{*}}$ Muhammad Dian Ruhamak ${ }^{*}$ Yudiarto Perdana $^{3}$ \\ ${ }^{1,2,3}$ Economics Faculty, Kadiri University, Kediri, Jawa Timur, Indonesia \\ "Corresponding author. Email: nindi.vaulia@unik-kediri.ac.id
}

\begin{abstract}
This study aims to determine the determinants of capital structure of cigarette companies in Indonesia. The data used in this study are for period of 2015-2019. The sample used was a cigarette company registered in IDX Analysis using partial adjustment model to identify liquidity, profitability, growth opportunity, company size, business risk factors and NDTS on capital structure. The analysis shows variables that have a significant effect on tobacco companies vary between companies. The results of the study can be a consideration for company managers cigarettes in Indonesia to consider the current determinant factors make changes in capital or other financial decisions. Research result also provides information for investors related to investment risks in cigarette companies in Indonesia
\end{abstract}

Keywords: capital structure,liquidity, profitability, growth opportunity, company size, business risk, NDTS.

\section{INTRODUCTION}

The capital structure decision for the company is an important decision for the company, because the capital structure is a combination of loans and capital for the long term. The right combination of capital structure will have an impact on the company and the prosperity of stockholder [1]. Decision making regarding capital structure is a decision that must be taken carefully by the firm as the chosen options have different impacts [2].

the composition of the capital structure of a publicly traded firm uses internal funds from retained earnings while external funds come from loans from outside parties, both long term debt and short term debt [3]. Reference of the capital structure theory, it can be said that the capital structure is a solution to increasing the productivity and performance of the firm because the goal of capital structure is the firm value optimization in long term.

Trade off theory, pecking order and agency cost theory are the basic theories used in the composition of capital structure. Trade off theory is a theory that is used to determine the optimal debt ratio used by firm, this theory explain that the optimal capital structure is achieved when obtaining added value from the use of debt due to tax savings as a result of interest expense.[4].

Pecking order theory was born as the result of a research that was conducted by Myers (1984) whose research stated that the firm has the choice in choosing its capital structure, where the firm prefers to use internal funds rather than external funds in business financing. This theory explains that when internal funds are insufficient, external financing will be chosen in the form of bond issue, meanwhile the issue of the news stock is the last alternative [5].

Agency Cost Theory explains that the optimal capital structure can be achieved when the conflict costs of various parties involved can be minimized[6]. Liquidity, profitability, growth opportunities, business risks, company size, and non-debt tax shield are determinants in the capital structure that plays a role important to firm funding decision [7].

The cigarette company is one of the consumer goods 
sector companies that have a large market in the country or abroad. The cigarette industry is an industry that has a role in contributing taxes, but the data actually shows that the cigarette industry does not experience an increase in capital structure. This shows that research needs to be conducted related to the determinants of capital structure in cigarette companies listed on IDX.

\subsection{Theory Study}

\subsubsection{Connection between Liqudity And Capital Structure}

Funding decisions both internal and external funding are important in supporting the firm operational activities. Some theories explain that the company will choose the funding structure by taking the basis of various benefits and costs associated with external funding through debt and equity [8]. Liquidity is called the company's ability to meet short-term financial obligations, the company's liquidity is indicated by the amount of small or small liquidity assets [9]. Companies with good liquidity show that the company has good internal financing to fulfill obligations so that the capital structure owned is also reduced [10]. The pecking order theory states that companies will choose to use internal funds in investing compared to external ones, thus showing that liquidity influences the company's capital structure [11]

\subsubsection{Connection between profitability And Capital Structure}

Profitability explains the company's ability to generate profits in a predetermined period [1]. A firm with high profitability also shows the capacity of companies in conducting funding using retained earnings [9]. Increased profitability will reduce the desire of firm to choose external funds, there is even a tendency for companies with high profitability to make payments on debts owned by the company, so that the level of debt in the capital structure is also reduced [12]

\subsubsection{Connection between Growth Opportunity And Capital Structure}

The company's growth is an opportunity for the company to develop in the future. according to [13]. Companies with growth opportunities will try to keep the firm debt ratio low, this condition is done as a motive to guard when conditions are difficult; this condition shows that when the opportunity for company growth is high, then the company's debt in the capital structure also falls. However, according to pecking order theory, a growing firm would rather use debt than use its own capital. This condition is shown by research conducted in China [14].

\subsubsection{Connection between Business Risk And Capital Structure}

Business risk is associated with operating leverage, which explain a fixed cost in operating expenses. When a company has fixed costs in its operational expenses, the greater the business risk, the higher the business risk of the company. This condition shows that the higher the business risk of the company, the lower the company uses debt in financing [15]. The concept is a company with certain risks in its operational activities, namely when a company uses debt, business risk will be charged by common stockholder [15]

\subsubsection{Connection between firm size And Capital Structure}

The size of the firm is indicated by the total assets, the number of sales, and the average sale which is also an illustration for investors related to the firm financial capability in one period [16]. A firm with relatively large size will tend to choose the use of external funds; this condition occurs because the funds needed are increasing along with the company's growth. According to pecking order theory, when a company experiences a lack of internal funds, it will choose external funds in the form of debt. When the size of the company is projected by the total assets owned are quite large, the company will easily obtain collateral for external funding, the research of [16] explains that firm size give effect the capital structure.

\subsubsection{Connection between Non Debt Tax Shield And Capital Structure}

Taxes can be a component to achieve optimal capital structure models both personally and as a body. Non debt tax shield is a tax advantage that appears apart from the composition of the loan or debt interest. NDTS is a tax savings due to the depreciation or depreciation of tangible assets that affect the capital structure [17]. This condition arises because the tax reduction from depreciation will substitute tax benefits from credit funding, so companies with high NDTS will minimize debt funding which also effect on capital [18]

\subsection{Research Methods}

This type of research is explanatory research that explains the causal relationship between independent variables with the dependent variable. The approach that is used in this study is a quantitative approach. The object of research is a cigarette company registered with IDX during the 2015- 2019 periods, consisting of HMSP (Hananjaya Mandala Sampoerna Tbk); GGRM (PT Gudang Garam, Tbk), RMBA (Bentoel International Investama Tbk); WIIM (wismilak Inti Makmur Tbk). The dependent variable in this study is the capital structure, with liquidity, profitability, growth opportunities, business risk, company size, and non debt tax shield as the independent variables. Data processing methods by estimating the research model that has been formed then conducted a hypothesis test on the estimation results, so that the hypothesis test can see the relationship between the dependent variable and the dependent variables. This study examines the variables of capital structure determinants consisting of liquidity, profitability, growth opportunities, business risk, company size, and non debt tax both individually and collectively using panel data. Panel data is data using time series that is combined with cross section

$$
\mathrm{CS}=\alpha+\beta \text { Liq }+\beta 2 \text { PROFit }+\beta 3 \text { GROWit }+\beta 4 \text { Risk }+
$$
$\beta 5$ SIZEit $+\beta 6$ NDTS 


\subsection{Results and Discussion}

\subsubsection{Liquidity and capital Structure}

The results of panel data regression with FEM model explain that liquidity has a negative relationship to the capital structure of cigarette companies, the results of this study support research [19] which explain that there will be a decrease in liquidity, and it will have an impact on debt, while companies with high liquidity also has the ability to pay off short-term debt so that debt is reduced and capital structure is low. The results of this study also support pecking order theory

\subsubsection{Profitability And Capital Structure}

Profitability is the company's ability to generate profits by making the most of its resources. The results of FEM panel data show that profitability has a negative relationship with capital structure. These results indicate that the higher the level of profitability generated by the company, the debt funding taken by the company is lower, this condition occurs because when rising profitability the company will prefer internal funding through retained earnings rather than debt, and this causes the company to have an optimal debt ratio . These results are consistent with the pecking order theory and also research from [10], that explains that profitability affect the arrangement of the optimal capital structure.

\subsubsection{Growth Opportunity And Capital Structure}

The results of the analysis of growth opportunity the firm using the FEM model explain that there is a significant negative relationship with the capital structure. This is consistent with research conducted by

[13] because when the higher the company growth, the debt used is also lower. This can be explained because the growing company has a higher risk so the company will minimize debt funding and increase funding by using its equity.

\subsubsection{Business Risk And Capital Structure}

Business risk is the risk borne by the company when being unable to cover operational costs, where this condition is influenced by revenue and cost stability [1]. Companies with high business risks will choose to reduce external funding or debt, so this risk is taken so that the company has greater risk. The results of research on cigarette factories show that increased business risk has an impact on debt policy decline. This study supports research conducted by [12] which explains that business risk greatly influences the company's capital structure decisions.

\subsubsection{Firm size And Capital Structure}

The size of the firm explains that the larger the size of the firm, the firm prefers to internal funding through retained earnings [1]. The results showed negative results which means that the size of a company that is increasingly large will be more resistant to bankruptcy risk because companies prefer funding through retained earnings compared to debt or external funds [8]

\subsubsection{Non Debt Tax Shield And Capital Structure}

The results of data analysis using FEM explain that NDTS has a negative influence on the capital structure of cigarette companies listed on IDX, the results of this study are in line with research [17] and pecking order theory which states that the value of NDTS can be a cause of debt reduction when there is an increase income so that the external capital structure is decrease [17]

\section{CONCLUSION}

Liquidity has an impact on debt, where companies with high liquidity also have the ability to pay off short-term debt so that debt is reduced and capital structure becomes decreases.

The higher the level of profitability produced by the company, the debt funding taken by the company is lower. This condition occurs because when profitability increases, the company will prefer internal funding through retained earnings rather than debt.

The higher the growth of the company, the debt used is also lower the effect of capital structure also decreases. This can be explained because the growing company has a higher risk so the company will minimize debt funding and increase funding by using its equity Business risk has an impact on the structure of external capital that is not optimal due to the increase in business risk has an impact on the decline in debt policy.

The results of the study indicate that the larger the size of the company, it will be more resistant to bankruptcy risk so that the structure of external capital also decreases. NDTS has a negative influence on capital structure because NDTS is the cause of debt reduction when there is an increase in income so that the external capital structure is decreases

\section{ACKNOWLEDGMENT}

This research was supported by Simlitabmas Grant Program, with "Penelitian Dosen Pemula" sceme fiscal year 2020. Author also thanks to Kadiri University for giving support completing this reaearch. We acknowledgment to all our family and colleges whosw motivate us during process of this research.

\section{REFERENCES}

[1] E. F. B. J. F. HOUSTON, Fundamental of Financial Management, 13th ed. USA: Integra Software Service Pvt. Ltd, 2011.

[2] C. I. D. Novitayanti and H. Rahyuda, "Determinan Struktur Modal Berdasarkan Pecking Order Theory Pada Perusahaan Sektor Barang Konsumsi Di Bei," J. Manaj. Univ. udayana, vol. 7, no. 8, pp. 44754507, 2018

[3] M. Onofrei, M. Brindusa, C. Durdureanu, and S. Gabriel, "Determinant factors of firm leverage : An 
empirical analysis at Iasi county level," Procedia Econ. Financ., vol. 20, no. 15, pp. 460-466, 2015.

[4] B. Grady, "The Effect of the Financial Crisis of 2007 - 2009 on the Capital Structure of Oil and Gas Firms," 2017.

[5] I. T. Tsl, R. S. Innowacji, and R. S. Rozwoju, "Determinants of the capital structure of TSL sector enterprises," vol. 22, no. 1, pp. 122-139, 2018.

[6] S. Antwi, E. Fiifi, E. Atta, K. Polytechnic, and P.O. B. Kf, "Capital Structure and Firm Value : Empirical Evidence from Ghana," vol. 3, no. 22, pp. 103-111, 2012.

[7] D. Hailegebreal and M. Wang, "Determinants of Capital Structure of African Firms : A Categorical Analysis," vol. 10, no. 1, pp. 1-14, 2018.

[8] S. Tripathy and A. Rahman, "Leverage and firm performance : Empirical evidence from Indian food processing industry," vol. 10, pp. 1233-1240, 2020.

[9] J. Chan, M. Phooi, M. Rahman, and S. Sannacy, "The determinants of capital structure: Evidence from public listed companies in Malaysia, Singapore and Thailand The determinants of capital structure: Evidence from public listed companies in Malaysia, Singapore and Thailand," Cogent Econ. Financ., vol. 6, no. $1,2018$.

[10] S. Pepur, M. Ćurak, and K. Poposki, "Corporate capital structure: the case of large Croatian companies," vol. 9664, no. June, 2016.

[11] S. Arsov and A. Naumoski, "Determinants of capital structure: An empirical study of companies from selected post-transition," vol. 34, no. 1, 2016.
[12] X. Vinh and C. Ellis, "An empirical investigation of capital structure and firm value in Vietnam," vol. 22, pp. 2016-2018, 2017.

[13] R. Haron, "Firm Level , Ownership Concentration And Industry Level Determinants Of Capital Structure In An Emerging Market : Indonesia," vol. 14, no. 1, pp. 127-151, 2018.

[14] H. Liu, Y. Zhang, and S. Gao, "Dividend tax and capital structure: Evidence from China," China J. Account. Stud., no. August 2015.

[15] J. Nwachukwu and D. Mohammed, "Business Risk, Industry Affiliation, and Corporate Capital Structure : Evidence From Publicly Listed Nigerian Companies," vol. 13, no. 1, pp. 5-15, 2012. J. Koralun-bereźnicka, "Firm size and debt maturity as indirect determinants of capital structure : evidence form European panel data," Appl. Econ. Lett., vol. 0, no. 0, pp. 1-4, 2017.

[16] Q. Zafar, W. Wongsurawat, and D. Camino, "Cogent Economics \& Finance The determinants of leverage decisions : Evidence from Asian emerging markets The determinants of leverage decisions : Evidence from Asian emerging markets," Cogent Econ. Financ., vol. 7, no. 1, 2019.

[17] G. Schjelderup, "The Tax Sensitivity of Debt in Multinationals: A Review The Tax Sensitivity of Debt in Multinationals : A," vol. 1516, no. February, 2016.

[18] H. Wang, Q. Xu, and J. Yang, "Investment timing and optimal capital structure under liquidity risk," vol. 4364, no. August, 2017. 